\title{
Penentuan Panjang Optimal Data Deret Waktu Bebas Outlier dengan Menggunakan Metode Window Time
}

\author{
Rya Sofi Aulia dan Raden Mohamad Atok \\ Jurusan Statistika, Fakultas Matematika dan Ilmu Pengetahuan Alam, Institut Teknologi Sepuluh Nopember (ITS) \\ Jl. Arief Rahman Hakim, Surabaya 60111 Indonesia \\ e-mail: ryasofia@gmail.com,radenatok@gmail.com
}

\begin{abstract}
Abstrak-Data outlier sering kali mempengaruhi model data secara umum sehingga pengaruh dari data outlier tersebut harus dikurangi atau dihilangkan. Namun, di sisi lain outlier merupakan data yang sangat informatif apabila penyebab adanya outlier tersebut diketahui sehingga beberapa penelitian merekomendasikan untuk tidak menghilangkan outlier namun mengganti model awal dengan model baru yang disisipkan dengan model outlier. Kemunculan outlier dapat menyebabkan bias yang cukup serius dalam estimasi parameter. Atas dasar penelitianpenelitian yang dilakukan sebelumnya maka pada penelitian ini dilakukan metode baru untuk mendeteksi outlier. Tujuan dari metode ini adalah untuk mendapatkan panjang data optimum yang bisa digunakan untuk mendeteksi data outlier. Penelitian ini terfokus pada pendeteksian outlier pada data deret waktu dengan jumlah data yang banyak. Dari hasil simulasi data dan implementasi yang dilakukan pada data riil didapatkan hasil bahwa window time 500 dan 1000 memberikan nilai akurasi deteksi outlier lebih baik dibandingkan dengan window time 100. Selain itu, metode deteksi menggunakan window time memberikan hasil yang lebih baik dibandingkan metode deteksi outlier biasa.
\end{abstract}

\section{Kata Kunci-Data Bebas Outlier, Outlier, Window Time}

\section{PENDAHULUAN}

$\mathrm{M}$ ODEL time series secara umum digunakan untuk mempelajari kehomogenan pola memory pada data time series. Keberadaan data-data outliers maupun perubahan struktural data menurunkan efisiensi dalam estimasi model autoregressive (AR). Outlier dan perubahan struktural data merupakan suatu hal yang umum ditemui dalam analisis data time series sehingga dapat menghasilkan kesimpulan yang salah. Data outlier merupakan data observasi yang memiliki karakteristik yang berbeda dengan data lainnya. Outlier dibedakan menjadi 4 jenis yaitu Additional Outlier (AO), Innovation Outlier (IO), Temporary Change (TC) dan Level Shift (LS).

Untuk mengidentifikasi model parameter yang paling baik, maka data-data outlier harus dideteksi dengan cara menghilangkan pengaruh outlier maupun menghilangkan data outlier tersebut. Berbagai macam metode outlier telah dicobakan oleh beberapa peneliti.

Tsay (1986) melakukan penelitian mengenai spesifikasi model time series ketika ditemukan outlier pada data deret waktu [1]. Data outlier merupakan suatu kejadian yang wajar terjadi dan sering kali muncul dalam analisis data, termasuk data time series. Pengaruh dari adanya data outlier bisa menyebabkan bias atau salah prediksi pada model data time series tersebut. Kemudian Tsay (1988) kembali melakukan penelitian tentang outliers, level shift dan perubahan varians dalam data deret waktu [2]. Ketiga jenis kejadian ini mempengaruhi stabilitas model time series. Namun terkadang keberadaannya sering diabaikan dan pengaruhnya diremehkan dampaknya.

Parameter dari model time series dan pengaruh outlier dapat pula diestimasi secara bersama [3]. Outlier merupakan data yang kemunculannya tidak bisa diprediksi karena terdapat berbagai macam faktor yang dapat menjadi penyebab munculnya outlier tersebut. Outlier dapat memberikan pengaruh yang cukup signifikan pada hasil identifikasi, estimasi parameter dan hasil peramalan. Metode yang digunakan adalah deteksi outlier secara iteratif untuk mendapatkan estimasi parameter dari model time series dan pengaruh outlier secara bersama. Kemudian dilakukan penelitian tentang pendeteksian perubahan sementara pada model data ARMA $(1,1)$ [4]. Pengaruh outlier diatasi dengan menggunakan dua cara (a) mengganti data outlier dengan nilai data lain yang bukan outlier dan (b) menghapus data outlier.

Pada metode deteksi outlier yang dilakukan oleh penelitipeneliti sebelumnya, outlier yang terkandung di dalam suatu data dapat dideteksi dengan menggunakan hasil spesifikasi model yang masih mengandung outlier sehingga bisa terjadi kesalahan hasil prediksi keberadaan outlier serta hasil forecasting-nya. Namun, pada penelitian yang akan dilakukan ini spesifikasi model dibangun dari data yang bebas outlier sehingga diharapkan dapat meningkatkan keakuratan hasil deteksi outlier.

Selain melakukan deteksi outlier dengan menggunakan keseluruhan data, dapat dilakukan dengan cara pemodelan window time yaitu memodelkan dengan semua data in sampel kemudian model yang diperoleh akan digunakan pada masingmasing window time yang telah dibentuk [5]. Berpedoman pada cara tersebut, deteksi outlier dengan pembagian window time dapat dilakukan dengan cara yang sama. Misalnya, data in sampel yang digunakan sebanyak 4800 data, kemudian model yang diperoleh dari data tersebut digunakan untuk memprediksi keberadaan outlier pada 100 data terakhir. Apabila terdapat outlier, maka outlier tersebut dihilangkan, namun apabila tidak ada outlier maka 100 data terakhir yang bebas outlier tersebut dimodelkan untuk memprediksi keberadaan 200 data terakhir, dan seterusnya.

Kemunculan outlier dapat menyebabkan bias yang cukup serius dalam estimasi parameter model AR. Atas dasar penelitian-penelitian yang dilakukan sebelumnya maka pada 
penelitian ini dilakukan prosedur baru untuk mendeteksi outlier yang ada pada data time series sehingga nantinya akan diperoleh panjang data optimum yang bisa digunakan untuk mendeteksi data outlier pada data deret waktu dengan jumlah data yang banyak.

\section{TINJAUAN PUSTAKA}

\section{A. Analisis Time Series}

Dasar pemikiran time series adalah pengamatan sekarang $\left(Z_{t}\right)$ tergantung pada satu atau beberapa pengamatan sebelumnya $\left(Z_{t-k}\right)$. Untuk melihat adanya korelasi antar pengamatan, dapat dilakukan uji korelasi antar pengamatan yang sering dikenal dengan Autocorrelation Function (ACF). Metode yang digunakan untuk data time series antara lain adalah metode ARIMA Box-Jenkins yang digunakan untuk mengolah time series yang univariat [6]. Misal $Z_{1}, Z_{2}, \ldots, Z_{t}$ merupakan proses stokastik untuk runtun waktu diskrit. Proses di atas disebut stasioner jika mean dan variansinya konstan untuk setiap titik $t$ dan kovarian yang konstan untuk setiap selang waktu ke- $k$ [7].

\section{B. Autoregressive Integrated Moving Average (ARIMA)}

Model Autoregressive Integrated Moving Average (ARIMA) merupakan model ARMA nonstasioner yang telah di-differencing sehingga menjadi model stasioner. Model ARIMA yang stasioner dan invertible dapat dituliskan:

$$
\phi(B) Z_{t}=\theta(B) a_{t}
$$

dimana $\quad \phi(B)=\left(1-\phi B-\phi^{2} B^{2}-\ldots-\phi^{p} B^{p}\right)$ dan $\theta(B)=\left(1-\theta B-\theta^{2} B^{2}-\ldots-\theta^{q} B^{q}\right) \quad B$ adalah operator backshift dan $a_{t}$ adalah residual white noise. Persamaan 1 dapat ditulis sebagai: $Z_{t}=\frac{\theta(B)}{\phi(B)} a_{t}$

Jika asumsi stasioneritas dalam varians tidak terpenuhi maka dilakukan transformasi Box-Cox dengan rumus seperti pada persamaan (2) dengan $\lambda$ merupakan nilai konstanta rounded value yang digunakan.

$$
T\left(Y_{t}\right)=\left\{\begin{array}{l}
\frac{Y_{t}^{\lambda}-1}{\lambda}, \lambda \neq 0 \\
\log \left(Y_{t}\right), \lambda=0
\end{array}\right.
$$

Estimasi parameter ARIMA dilakukan dengan menggunakan metode Maximum Likelihood Estimator (MLE) dengan memaksimumkan fungsi kepadatan peluang pada rumus (3) dimana $\boldsymbol{a}=\left(a_{1}, a_{2}, \ldots, a_{T}\right)^{\prime}$ dan $a_{t} \sim N\left(0, \sigma_{a}^{2}\right)$.

$$
P\left(\boldsymbol{a} \mid \phi, \mu, \theta, \sigma_{a}{ }^{2}=\left(2 \pi \sigma_{a}{ }^{2}\right)^{-\frac{T}{2}} \exp \left(-\frac{1}{2 \sigma_{a}^{2}} \sum_{t=1}^{T} a_{t}{ }^{2}\right)\right.
$$

Setelah parameter diestimasi, maka kemudian dilakukan pengujian signifikansi parameter menggunakan statistik uji pada rumus (4) untuk parameter AR. Nilai hipotesis nol, yaitu $\mathrm{H}_{0}: \phi_{i}=0$ untuk parameter AR dimana $i=1,2, \ldots, p$ dan $\mathrm{H}_{0}$ : $\theta_{j}=0$ untuk MA dengan $j=1,2, \ldots, q$ akan ditolak apabila nilai statistik uji untuk AR yaitu $\left|t_{\text {hitung. } i}\right|>t_{\alpha / 2,\left(T-n_{p}\right)}$

$$
t_{\text {hitung.i }}=\frac{\hat{\phi}_{i}}{S E\left(\phi_{i}\right)}
$$

Pengujian asumsi white-noise dilakukan menggunakan uji Ljung-Box seperti pada rumus (5) dengan hipotesis nol, yaitu $\mathrm{H}_{0}: \rho_{1}=\rho_{2}=\mathrm{L}=\rho_{k} \mathrm{~L}=\rho_{K}=0$ dan $\mathrm{H}_{1}$ : minimal ada satu nilai $\rho_{k} \neq 0$ dimana $k=1,2, \mathrm{~L}, K . \mathrm{H}_{0}$ ditolak apabila nilai statistik uji Q bernilai lebih besar dari $\chi^{2} K_{-p-q, \alpha}$ dimana nilai $p$ adalah banyaknya parameer AR pada model dan $q$ adalah banyaknya parameter MA pada model.

$$
Q=T(T+2) \sum_{k=1}^{K} \frac{\hat{\rho}_{k}{ }^{2}}{T-k}
$$

Uji normalitas dilakukan dengan menggunakan uji Kolmogorov-Smirnov dengan statistik uji seperti pada rumus (6) dimana:

$\mathrm{H}_{0}: F\left(a_{t}\right)=F_{0}\left(a_{t}\right)$ (Residual berdistribusi normal)

$\mathrm{H}_{1}: F\left(a_{t}\right) \neq F_{0}\left(a_{t}\right)$ (Residual tidak berdistribusi normal)

$$
D=\operatorname{Sup}\left|F\left(a_{t}\right)-F_{0}\left(a_{t}\right)\right|
$$

\section{Evaluasi Model}

Pada penelitian ini, evaluasi model dan pemilihan model terbaik akan dilakukan menggunakan kriteria nilai root mean square error (RMSE). Semakin kecil nilai RMSE maka dapat dikatakan bahwa model semakin baik. Nilai RMSE out-sample didapatkan dari rumus (7) [8].

$$
R M S E_{\text {out }}=\sqrt{M S E_{\text {out }}}=\sqrt{\frac{1}{N} \sum_{t=1}^{N}\left(Z_{t}-\hat{Z}_{t}\right)^{2}}
$$

\section{Jenis Outlier}

Additive outlier adalah kejadian yang mempunyai efek pada data time series hanya pada satu periode saja. Bentuk umum sebuah Additive Outliers (AO) dalam proses ARMA diuraikan sebagai berikut:

$$
\begin{aligned}
Z_{t} & = \begin{cases}X_{t} & t \neq T \\
X_{t}+\omega & t=T\end{cases} \\
& =X_{t}+\omega_{A O} I_{t}^{(T)} \\
& =\frac{\theta(B)}{\phi(B)} a_{t}+\omega_{A O} I_{t}^{(T)}
\end{aligned}
$$

adalah variabel indikator yang mewakili ada atau tidak adanya outlier pada waktu T.

Innovational outliers adalah kejadian yang efeknya mengikuti proses ARMA. Bentuk umum sebuah innovational outliers didefinisikan sebagai berikut:

$$
Z_{t}=X_{t}+\frac{\theta(B)}{\phi(B)} \omega_{I O} I_{t}^{(T)}=\frac{\theta(B)}{\phi(B)}\left(a_{t}+\omega_{I O} I_{t}^{(T)}\right)
$$

TC adalah kejadian dimana outlier menghasilkan efek awal sebesar $\omega$ pada waktu t, kemudian secara perlahan sesuai dengan besarnya $\delta$. Model TC dituliskan sebagai berikut:

$$
\begin{aligned}
Z_{t} & =X_{t}+\frac{1}{(1-\delta B)} \omega_{T C} I_{t}^{(T)} \\
& =\frac{\theta(B)}{\phi(B)} a_{t}+\frac{1}{(1-\delta B)} \omega_{T C} I_{t}^{(T)}
\end{aligned}
$$


Pada saat $\delta=0$ maka TC akan menjadi kasus additive outlier, sedangkan pada saat $\delta=1$ maka TC akan menjadi kasus level shift.

Suatu LS adalah kejadian yang mempengaruhi deret pada satu waktu tertentu yang memberikan suatu perubahan tiba-tiba dan permanen. Model outlier LS dinyatakan sebagai:

$$
\begin{aligned}
Z_{t} & =X_{t}+\frac{1}{(1-B)} \omega_{L S} I_{t}^{(T)} \\
& =\frac{\theta(B)}{\phi(B)}+\frac{1}{(1-B)} \omega_{L S} I_{t}^{(T)} \\
& =\frac{\theta(B)}{\phi(B)}+\omega_{L S} S_{t}^{(T)}
\end{aligned}
$$

\section{E. Metode Window Time}

Istilah window time berkaitan erat dengan konsep drift [9]. Terdapat lima macam jenis pembagian jendela yang digunakan dalam pemodelan yaitu full memory dan no memory, fixed size dan adaptable size, serta batch selection.

Metode window time full memory mengasumsikan bahwa mengabaikan window time sebelumnya tidak diperlukan dalam pemodelan. Model dihasilkan dari semua window time pada interval sebelumnya dan observasi terbaru ditambahkan ke window time yang tergabung dalam interval. Sementara itu, tidak ada window time lama yang dihapus dari lebar jendela. Acuan no memory window time adalah menggunakan jendela dengan ukuran yang tetap dari satu kumpulan data. Metode ini mengasumsikan bahwa kumpulan data pembentuk tidak berhubungan dengan konsep data saat ini, dan model baru harus dibangun dari kumpulan data terbaru pada setiap titik waktu yang baru pula dengan mengabaikan semua informasi lama. Permasalahan utama fixed size window time adalah bagaimana memilih ukuran jendela yang sesuai. Untuk adaptable size window time, ukuran jendela disesuaikan oleh beberapa mekanisme. Adaptif window time dapat ditetapkan dengan heuristik, yaitu melibatkan beberapa parameter [10].

\section{F. Uji ANOVA}

Analisis of variance atau ANOVA merupakan salah satu uji parametrik yang berfungsi untuk membedakan nilai rata-rata lebih dari dua kelompok data dengan cara membandingkan variansinya [11]. Prinsip uji ANOVA adalah melakukan analisis variabilitas data menjadi dua sumber variasi yaitu variasi di dalam kelompok (within) dan variasi antar kelompok (between). Untuk menganalisis data dengan faktor yang lebih banyak dapat menggunakan Multi Way ANOVA. Untuk memudahkan perhitungan ANOVA, maka dapat digunakan tabel ANOVA yang ditunjukkan oleh Tabel 1 berikut.

Tabel 1.

Pengujian Multi Way ANOVA

\begin{tabular}{cccc}
\hline $\begin{array}{c}\text { Source of } \\
\text { Variation }\end{array}$ & $\mathrm{SS}$ & $\mathrm{MS}$ & $\mathrm{F}$ \\
\hline Faktor A & $\sum_{i=1}^{a} n_{i}\left(\bar{y}_{i}-\bar{y}_{. .}\right)^{2}$ & $\frac{S S A}{(a-1)}$ & $\frac{M S A}{M S E}$ \\
Faktor B & $\sum_{j=1}^{b} n_{j}\left(\bar{y}_{j}-\bar{y}_{. .}\right)^{2}$ & $\frac{S S B}{(b-1)}$ & $\frac{M S B}{M S E}$
\end{tabular}

$$
\begin{array}{cccc}
\text { Faktor C } & \sum_{k=1}^{a} n_{k}\left(\bar{y}_{k}-\bar{y}_{. .}\right)^{2} & \frac{S S C}{(c-1)} & \frac{M S C}{M S E} \\
\text { Faktor D } & \sum_{l=1}^{a} n_{l}\left(\bar{y}_{l}-\bar{y}_{. .}\right)^{2} & \frac{S S D}{(d-1)} & \frac{M S D}{M S E} \\
\text { Error } & \substack{\text { SST-SSA- } \\
\text { SSB-SSC- } \\
\text { SSD }} & \frac{S S E}{(a-1)(b-1)(c-1)(d-1)} \\
\text { Total } & \sum_{i=1}^{a} \sum_{j=1}^{b} \sum_{k=1}^{c} \sum_{l=1}^{d}\left(y_{i j k l}-\bar{y}_{. . .}\right)^{2}
\end{array}
$$

\section{METODOLOGI PENELITIAN}

Data yang digunakan merupakan simulasi dari data deret waktu dengan model ARIMA $(1,0,0)$ dengan $\phi=0.8,-0.8,0.5$ dan - 0.5 Kemudian pada masing-masing data tersebut disisipkan outlier tunggal di dalamnya. Panjang data yang disimulasikan sebanyak 5000 data, critical value yang digunakan sebesar $4, \delta=0.7$ dan besarnya outlier ditentukan sebesar 4. Langkah penelitian yang digunakan dalam analisis adalah sebagai berikut.

1. Membangkitkan data simulasi masing-masing 100 data dengan model ARIMA $(1,0,0)$ dengan besar parameter yang ditentukan dan panjang data sebanyak 5000 dengan residual yang memenuhi IIDN $(0,1)$.

2. Memvalidasi masing-masing model yang telah dibangkitkan apakah sesuai dengan model penelitian yang diinginkan.

3. Menambahkan efek outlier tunggal pada masing-masing model data. Empat jenis outlier yang disisipkan adalah AO, IO, TC dan LS. Masing-masing penyisipan outlier tersebut dikombinasi dengan lokasi outlier tersebut diletakkan yaitu di awal $(\mathrm{T}=1300)$, tengah $(\mathrm{T}=2500)$ dan akhir data $(\mathrm{T}=3700)$. Sehingga terdapat 36 kombinasi yang dihasilkan dari 3 model, 4 jenis outlier dan 3 lokasi yang berbeda.

4. Menghapus 100 data awal sehingga data yang akan digunakan dalam observasi sebanyak 4900 data.

5. Membagi data menjadi 4800 data in sampel dan 100 data out sampel.

6. Mendeteksi outlier yang ada dalam data dengan kombinasi panjang data awal yang dideteksi sebanyak 100, 500 dan 1000. Serta mengkombinasikan lokasi outlier yaitu di awal, tengah dan akhir data.

Metode baru yang akan dilakukan untuk menentukan panjang optimal data deret waktu bebas outlier dengan jumlah data awal yang digunakan sebanyak 100, 500 dan 1000 dengan panjang pergeseran sebesar 100 data.

a. Memodelkan data in sampel keseluruhan

b. Model yang didapatkan dari keseluruhan data in sampel tersebut digunakan untuk mendeteksi outlier pada 100 observasi in sample terakhir.

c. Apabila outlier terdeteksi maka outlier tersebut dikeluarkan dari series sampai tidak ada outlier lagi.

d. Setelah 100 observasi tersebut bersih dari outlier lalu dimodelkan. 
e. Model yang didapatkan dari 100 observasi terakhir tersebut digunakan untuk mendeteksi outlier pada 200 observasi in sample terakhir.

f. Apabila outlier terdeteksi maka outlier tersebut dikeluarkan dari series sampai tidak ada outlier lagi. Proses terus berlanjut sampai data observasi habis dan bersih dari outlier.

Dengan langkah-langkah yang sama dilakukan untuk panjang data awal yang diobservasi sebesar 500 dan 1000 yang terletak di awal dan tengah series.

7. Menghitung kesalahan pendeteksian outlier pada masing-masing data.

8. Membandingkan persentase kesalahan pendeteksian outlier pada masing-masing model.

9. Mendapatkan panjang optimal data yang dibutuhkan untuk memprediksi suatu data deret waktu dengan model ARIMA $(1,0,0)$ yang bebas outlier.

\section{HASIL DAN PEMBAHASAN}

\section{A. Data Simulasi}

Data simulasi dibangkitkan dari model ARIMA $(1,0,0)$ dengan 4 nilai parameter yang berbeda-beda baik parameter yang bernilai positif maupun negatif. Banyaknya deret yang dibangkitnya adalah 5000 observasi dan banyaknya perulangan yang dibangkitkan dalam setiap model adalah 100 kali. Kemudian, data simulasi tersebut disisipkan outlier dengan jenis Additional Outlier (AO), Innovational Outlier (IO), Temporary Change (TC) atau Level Shift (LS) di lokasi yang berbeda-beda. Critical value yang digunakan sebesar 4, begitu juga dengan besaran outlier ditentukan sebesar 4. Berikut merupakan data dengan model ARIMA $(1,0,0)$ yang dibangkitkan dengan 4 variasi parameter.

Tabel 2.

Empat Model yang Digunakan Dalam Simulasi

\begin{tabular}{cc}
\hline No. & Model \\
\hline 1. & $Z_{t}=-0,8 Z_{t-1}+a_{t}$ \\
2. & $Z_{t}=0,8 Z_{t-1}+a_{t}$ \\
3. & $Z_{t}=-0,5 Z_{t-1}+a_{t}$ \\
4. & $Z_{t}=0,5 Z_{t-1}+a_{t}$ \\
\hline \hline
\end{tabular}

Setiap model ARIMA $(1,0,0)$ dengan parameter yang sudah ditentukan tersebut dibangkitkan sebanyak 100 kali perulangan supaya memberikan hasil yang terbaik. Pada 100 observasi pertama di setiap data bangkitan dihapus karena pada awal proses bangkitan belum menghasilkan model ARIMA $(1,0,0)$ yang konvergen. Setiap data harus dilakukan validasi terlebih dahulu untuk memastikan bahwa data bangkitan mengikuti model yang diinginkan. Sehingga pada akhirnya dipilih 100 data untuk masing-masing model yang benar-benar valid mengikuti model ARIMA $(1,0,0)$ dengan parameter yang sesuai. Berikut merupakan time series plot dari data bangkitan setiap model.

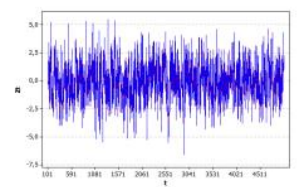

(a)

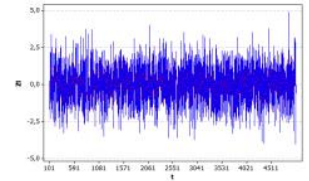

(c)

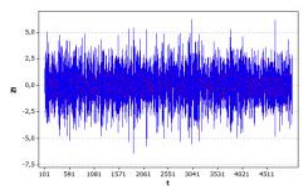

(b)

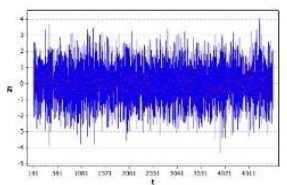

(d)
Gambar 1. Time Series Plot Model Simulasi Perulangan Pertama (a)

$Z=-0,8 Z+a$ (b) $Z=0,8 Z+a \quad$ (c) $Z=-0,5 Z+a \quad$ (d)

$Z=0,5 Z+a$

Setelah diperoleh 100 data dengan model yang valid dan sesuai dengan model bangkitan maka setiap data dibagi menjadi data in sample dan out sample. Dari 4900 observasi, data out sample yang digunakan sebanyak 100 data terakhir dan sisanya menjadi data in sample. Data in sample inilah yang kemudian akan disisipkan empat jenis outlier yang berbeda-beda.

\section{B. Penyisipan Outlier}

Dengan menggunakan data simulasi yang sama, masingmasing disisipkan outlier tunggal dengan jenis yang berbeda yaitu Additional Outlier (AO), Innovational Outlier (IO), Temporary Change (TC) atau Level Shift (LS) di lokasi yang berbeda yaitu depan $(T=1200)$, tengah $(T=2400)$ atau belakang $(\mathrm{T}=3600)$ dari keseluruhan data observasi.

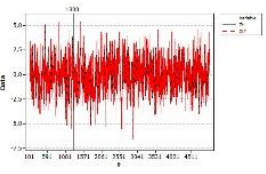

(a)

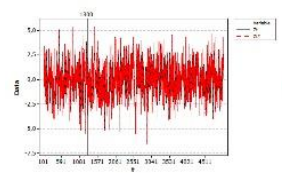

(d)

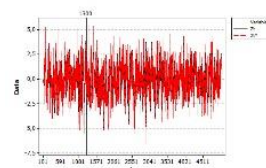

(g)

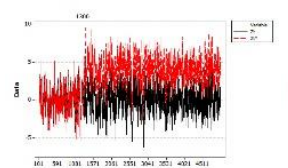

(j)

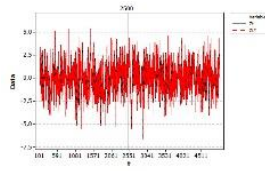

(b)

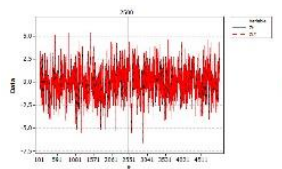

(e)

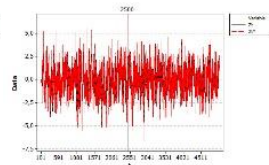

(h)

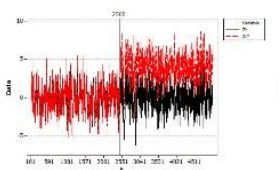

(k)

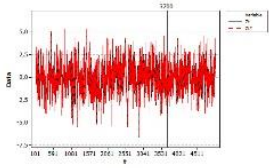

(c)

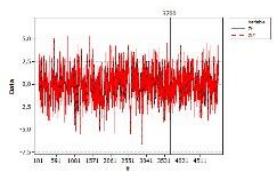

(f)

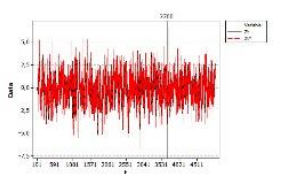

(i)

(1)

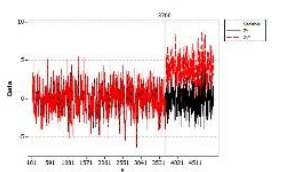

Gambar 2. Time Series Plot Model $Z_{t}=-0,8 Z_{t-1}+a$ Perulangan Pertama Setelah Penambahan outlier (a) AO $T=1200$ (b) AO $T=2400$ (c) AO $T=3600$ (d) IO $T=1200$ (e) IO $T=2400$ (f) IO $T=3600$ (g) TC $T=1200(\mathrm{~h}) \mathrm{TC} \quad T=2400$ (i) TC $T=3600(\mathrm{j})$ LS $T=1200(\mathrm{k}) \mathrm{LS}$ $T=2400$ (1) LS $T=3600$ 
Masing-masing jenis outlier memiliki karakteristik yang berbeda. Pada data simulasi ini, diberikan efek outlier tunggal yang lokasinya di depan yaitu pada $T=1200$, di tengah yaitu pada $T=2400$ dan di belakang yaitu pada $T=3600$. Besarnya efek outlier yang diberikan adalah $\omega=4$ dan $\delta=0.7$. Ilustrasi time series plot setelah penambahan efek outlier adalah seperti pada Gambar 2..

\section{Prosedur Deteksi Outlier Dengan Metode Window Time}

Dalam penelitian ini terdapat 4 faktor yang diduga berpengaruh terhadap kesalahan deteksi outlier yang terdapat pada data simulasi. Faktor pertama adalah parameter model AR(1) yang dibangkitkan yaitu $0.8,-0.8,0.5$ dan -0.5 . Faktor kedua adalah jenis outlier yang terdapat pada data yaitu AO, IO dan TC. Faktor ketiga adalah panjang window time awal yang dideteksi keberadaan windownya yaitu 100, 500 dan 1000. Dan faktor yang terakhir adalah lokasi keberadaan outlier yang disisipkan yaitu berada di depan $(\mathrm{T}=1200)$, tengah $(\mathrm{T}=2400)$ dan belakang $(\mathrm{T}=3600)$. Untuk menguji apakah keempat faktor yang disebutkan diatas berpengaruh terhadap kesalahan deteksi outlier dilakukan pengujian Multi Way ANOVA terhadap hasil data kesalahan deteksi outlier.

Sebagai contoh pada penyisipan tipe outlier AO yang diletakkan pada data observasi sebesar $\omega=4$ pada saat observasi ke 1200 pada model ARIMA $(1,0,0)$ dengan parameter $\phi=0.8$ pada model bangkitan perulangan pertama. Didapatkan hasil bahwa terdapat kesalahan deteksi outlier pada saat data observasi ke 1201 dan 2117. Data tersebut seharusnya bukan merupakan outlier, namun karena kesalahan deteksi maka data pada observasi tersebut dianggap sebagai outlier. Sedangkan data observasi ke-1200 dideteksi secara benar sebagai outlier. Sehingga terdapat 2 kesalahan deteksi outlier dan prosentase kesalahan deteksi outlier menjadi sebesar $0,042 \%$. Selanjutnya dilakukan prosedur yang sama untuk model perulangan berikutnya sampai pada data perulangan ke 100. Prosedur ini menghasilkan rata-rata prosentase kesalahan deteksi outlier sebesar $0.075 \%$ pada model dengan parameter $\phi=0.8$. Prosedur yang sama dilakukan pada parameter model yang berbeda dan lebar window awal yang berbeda pula.

LS merupakan kejadian yang mempengaruhi deret pada suatu waktu tertentu dan efek dari outlier tersebut membuat suatu perubahan yang tiba-tiba dan permanen sampai akhir periode. Metode yang paling baik untuk mengatasi jenis outlier ini adalah dengan menggunakan analisis intervensi step function karena dapat memodelkan pola data yang besarannya berubah secara permanen. Sedangkan dalam penelitian ini cara yang digunakan untuk mengatasi ketiga jenis outlier yang lain adalah dengan menghilangkan data yang terdeteksi sebagai outlier [3]. Sehingga untuk analisis deteksi outlier pada prosedur window time yang ada dalam penelitian ini tidak membahas hasil data simulasi yang disisipkan dengan outlier jenis level shift.

Salah satu faktor yang menjadi objek penelitian adalah pengaruh panjang awal window time terhadap kesalahan deteksi outlier. Tabel 3 merupakan rata-rata kesalahan deteksi outlier berdasarkan panjang window time awal yang diujikan yaitu 100,500 dan 1000 .
Tabel 3.

Rata-Rata Kesalahan Deteksi Outlier Berdasarkan Lebar Window Time Awal

\begin{tabular}{rrr}
\hline \hline No. & Window Time Awal & Rata-Rata (\%) \\
\hline 1. & 100 & 0,03957 \\
2. & 500 & 0,03445 \\
3. & 1000 & 0,03473 \\
\hline \hline
\end{tabular}

Prosentase rata-rata keslaahan deteksi outlier yang terjadi ketika dicobakan dengan lebar window time awal 100 adalah $0.03957 \%$, selanjutnya menurun ketika dicobakan pada window time yang lebih lebar yaitu 500 dengan rata-rata prosentase kesalahan deteksi sebesar $0.03445 \%$. Ketika lebar window time sebesar 1000 menghasilkan prosentase sebesar $0.03473 \%$.

Salah satu asumsi yang diperlukan dalam pengujian Multi Way ANOVA adalah varians antar kelompok harus bersifat homogen. Untuk menguji kehomogenan varians antar kelompok digunakan Levene's Test seperti ditunjukkan pada Tabel 4 berikut.

Tabel 4 .

\begin{tabular}{cccc} 
Levene's Test & \multicolumn{3}{l}{ Untuk Menguji Homogenitas } \\
\hline$\underline{\mathrm{F}}$ & df1 & $\mathrm{df} 2$ & Sig. \\
\hline 13.622 & 107 & 10692 & 0.000 \\
\hline
\end{tabular}

Tabel 4 diatas menunjukkan bahwa nilai signifikansi sebesar 0.000 yaitu kurang dari nilai $\alpha=0.05$, sehingga dapat dikatakan varians antar kelompok secara signifikan bersifat homogen. Sehingga dapat dilakukan uji Multi Way ANOVA.

Pengujian Multi Way ANOVA dilakukan untuk mengetahui faktor-faktor apa saja yang mempengaruhi kesalahan deteksi outlier yang dilakukan pada data simulasi. Dalam penelitian ini diduga terdapat 4 faktor yang mempengaruhi kesalahan deteksi outlier yaitu besarmya parameter dalam model, jenis outlier yang ada dalam deret, lebar window time awal dan lokasi keberadaan outlier.

Berdasarkan nilai corrected model dapat disimpulkan bahwa semua variabel independen secara serentak berpengaruh terhadap prosentase kesalahan deteksi outlier. Hal ini ditunjukkan dengan nilai signifikansi sebesar 0.000 yaitu kurang dari nilai $\alpha=0.05$, sehingga dapat dikatakan bahwa model tersebut valid.

Nilai signifikansi dari empat faktor yang diduga berpengaruh terhadap prosentase kesalahan deteksi outlier bernilai 0.000 yaitu kurang dari nilai $\alpha=0.05$, berarti bahwa besarmya parameter dalam model, jenis outlier yang ada dalam deret, lebar window time awal dan lokasi keberadaan outlier berpengaruh signifikan terhadap kesalahan deteksi outlier. Parameter dalam model, jenis outlier dan lokasi keberadaan outlier merupakan faktor-faktor yang tidak bisa diubah dalam suatu data riil karena menjadi suatu karakteristik masingmasing yang menjadi ciri khas sebuah data. Dalam penelitian ini akan dibandingkan mengenai faktor lebar window time awal yang dapat diubah-ubah sesuai dengan penelitian.

Interaksi antar faktor yang berpengaruh signifikan terhadap kesalahan deteksi outlier adalah parameter* lebar window time awal dengan nilai signifikansi sebesar 0.018 , jenis outlier * lokasi outlier dengan nilai signifikansi sebesar 0.000 , parameter * jenis outlier * lokasi outlier dengan nilai signifikansi sebesar 0.000 dan jenis outlier* lebar window time awal * lokasi outlier dengan nilai signifikansi sebesar 0.034. Sedangkan interaksi lainnya tidak berpengaruh signifikan terhadap kesalahan 
deteksi outlier. Sebagai contoh, interaksi yang mengandung lokasi outlier dan lebar window time awal cenderung tidak signifikan karena pada pengamatan outlier diletakkan di luar 1000 observasi terakhir sedangkan lebar window time paling maksimum adalah 1000 observasi terakhir. Secara ideal, hal ini membuktikan bahwa pada semua lebar window time awal tidak akan dideteksi outlier sehingga tidak berpengaruh signifikan terhadap kesalahan deteksi outlier.

Dengan menggunakan Uji Tukey dapat diketahui kategori manakah dari lebar window time awal yang memiliki perbedaan secara signifikan. Tabel 5 berikut menunjukkan hasil dari Uji Tukey.

Tabel 5.

Hasil Uji Tukey Post Hoc

\begin{tabular}{lrrl}
\hline $\begin{array}{c}\text { Lebar window } \\
\text { time } \text { awal }\end{array}$ & $\begin{array}{c}\text { Lebar window } \\
\text { time awal }\end{array}$ & Selisih Rata-Rata & Sig. \\
\hline \multirow{2}{*}{100} & 500 & 0,00512 & 0,000 \\
& 1000 & 0,00483 & 0,000 \\
\multirow{2}{*}{500} & 100 & $-0,00512$ & 0,000 \\
& 1000 & $-0,00029$ & 0,969 \\
\multirow{2}{*}{1000} & 100 & $-0,00483$ & 0,000 \\
& 500 & 0,00029 & 0,969 \\
\hline
\end{tabular}

Dari Tabel 5 di atas dapat dilihat bahwa terdapat perbedaan signifikan antara lebar window time awal 100 dengan 500 dan 100 dengan 1000 dengan nilai signifikansi sebesar 0.000 yaitu kurang dari nilai $\alpha=0.05$. Sehingga selanjutnya perlu diteliti tentang rata-rata akurasi masing-masing lebar window time awal. Tabel 5 menjelaskan bahwa rata-rata prosentase kesalahan deteksi outlier kelompok dengan lebar window time awal 500 sebesar $0.03445 \%$ tidak berbeda secara signifikan dengan rata-rata prosentase kesalahan deteksi outlier kelompok dengan lebar window time awal 1000 sebesar $0.03473 \%$. Sedangkan rata-rata prosentase kesalahan deteksi outlier kelompok dengan lebar window time awal 100 yaitu sebesar $0.03957 \%$ berbeda secara signifikan dengan rata-rata prosentase kesalahan deteksi outlier kelompok dengan lebar window time awal 500 dan 1000. Karena nilai prosentase lebar window time awal 100 lebih besar dibandingkan dengan nilai prosentase lebar window time awal 500 dan 1000, maka lebar window time awal 500 dan 1000 memberikan akurasi yang lebih baik.

\section{Membandingkan Akurasi Hasil Prediksi}

Setelah mendapatkan hasil bahwa dengan lebar window time awal 500 dan 1000 memberikan nilai rata-rata prosentase kesalahan deteksi outlier yang lebih baik dibandingkan dengan lebar window time awal 100. Selanjutnya akan dibandingkan akurasi hasil prediksi dari data out sampel sebanyak 100 observasi yang akan digunakan dnegan 3 cara yaitu: (1) prediksi tanpa melakukan deteksi outlier pada data, (2) prediksi dengan melakukan deteksi outlier di keseluruhan data, dan (3) prediksi dengan melakukan deteksi outlier dan window time. Perhitungan akurasi dari nilai prediksi menggunakan nilai RMSE. Nilai prediksi akan semakin akurat apabila nilai RMSE yang dihasilkan semakin kecil.

Hasil perbandingan ketiga cara memberikan kesimpulan bahwa cara ketiga yaitu prediksi dengan melakukan deteksi outlier dan window time menghasilkan RMSE yang paling kecil pada model pertama, ketiga dan kedua yaitu $Z_{t}=-0,8 Z_{t-1}+a_{t}, \quad Z_{t}=-0,5 Z_{t-1}+a_{t}$ dan $Z_{t}=0,5 Z_{t-1}+a_{t}$ Sedangkan pada model kedua yaitu $Z_{t}=0,8 Z_{t-1}+a_{t}$ dengan parameter model -0.8 , cara ketiga tidak menghasilkan nilai RMSE yang paling kecil dibandingkan kedua cara yang lainnya. Sehingga dapat disimpulkan deteksi outlier dengan menggunakan window time menghasilkan akurasi yang baik jika parameter model $\phi=0.8, \phi=0.5$ dan $\phi=-0.5$. Pada penelitian ini hanya dicobakan pada keempat nilai parameter itu saja, namun tidak menutup kemungkinan untuk memberikan hasil pada parameter-parameter selain yang disebutkan untuk diteliti pada penelitian selanjutnya.

\section{E. Studi Kasus (Tree Rings)}

Data riil yang akan digunakan adalah data lingkar pohon yang ada di Chili. Data ini digunakan karena diduga memiliki model ARIMA yang sama dengan data simulasi yaitu ARIMA $(1,0,0)$. Data tersedia dalam website resmi www.datamarket.com dalam kategori tree rings. Data yang dijadikan observasi untuk pengujian studi kasus adalah tahun 1264 sampai dengan 1975. Sehingga terdapat 712 observasi yang diamati dalam time series. Selanjutnya 712 observasi tersebut dibagi menjadi 700 observasi in sample dan 12 observasi out sample. Pembagian ini ditentukan berdasarkan prosentase pembagian data in sample dan out sample yang dilakukan pada data simulasi, selain itu untuk memudahkan pemotongan window time yang dilakukan pada data observasi dengan pergeseran sebesar 100 observasi. Selanjutnya dilakukan spesifikasi model dengan tahap-tahap identifikasi model, estimasi dan signifikansi parameter dan diagnostic checking. Selanjutnya dihitung nilai prediksi dengan menggunakan 3 cara seperti pada data simulasi.

Ketiga cara yang dibandingkan pada data tree rings memberikan hasil bahwa cara pertama dan ketiga memiliki nilai RMSE yang sama sedangkan cara kedua memiliki nilai RMSE yang lebih kecil, nilai RMSE masing-masing cara ditunjukkan pada Tabel 6 berikut.

\begin{tabular}{rl} 
Tabel 6. \\
Perbandingan RMSE Ketiga Cara \\
\cline { 2 - 2 } Cara & RMSE \\
\hline 1 & 0.40891 \\
2 & 0.40945 \\
3 & 0.40891 \\
\hline \hline
\end{tabular}

Dengan menggunakan cara 1 dan 3 tidak terdeteksi outlier yang ada di dalam deret data, sedangkan jika menggunakan cara 2 terdeteksi outlier di dalam data sebanyak 15 outlier.

\section{KESIMPULAN}

Rata-rata prosentase kesalahan deteksi outlier kelompok dengan lebar window time awal 500 sebesar $0.03445 \%$ tidak berbeda secara signifikan dengan rata-rata prosentase kesalahan deteksi outlier kelompok dengan lebar window time awal 1000 sebesar $0.03473 \%$. Sedangkan rata-rata prosentase kesalahan deteksi outlier kelompok dengan lebar window time awal 100 yaitu sebesar $0.03957 \%$ berbeda secara signifikan dengan rata- 
rata prosentase kesalahan deteksi outlier kelompok dengan lebar window time awal 500 dan 1000. Karena nilai prosentase lebar window time awal 100 lebih besar dibandingkan dengan nilai prosentase lebar window time awal 500 dan 1000, maka lebar window time awal 500 dan 1000 memberikan akurasi yang lebih baik.

Beberapa hal berikut sebagai saran pada penelitian selanjutnya adalah pada penelitian selanjutnya disarankan untuk meneliti lebar window antara 500 dan 1000 karena, diduga rentang lebar window tersebut menghasilkan nilai prosentase akurasi yang optimal serta perlu dilakukan kombinasi parameter yang lebih beragam lagi, mengingat dalam penelitian ini terdapat satu parameter yang tidak menghasilkan kesimpulan yang sama dengan ketiga parameter yang diujicobakan.

\section{DAFTAR PUSTAKA}

[1] Tsay, R. S., 1986. Time Series Model Specification in the Presence of Outliers. Journal of the American Statistical Association, No. 393, Mar, Volume 81, pp. 132-140.

[2] Tsay, R. S., 1988. Outliers, Level Shifts, and Variance Changes in Time Series. Journal of Forecasting, Volume 7, pp. 1-20.

[3] Chen, C. \& Liu, L. M., 1993. Joint Estimation of Model Parameters and Outlier Effect in Time Series. Journal of the American.

[4] Atok, R. M. et al., 2015. Temporary Change Detection on ARMA(1,1) Data. International Journal of Mathematical Models and Methods in Applied Sciences, Volume 9, pp. 651-658.

[5] Hadi, A. F., 2016. Model Hibrida Kombinasi ARIMAX-NN dan GARCH untuk Peramalan Inflow dan Outflow Uang Kartal, Surabaya: s.n.

[6] Box, G. J. G. a. R. G., 1994. Time Series Analysis Forecasting and Control. 3rd edition penyunt. s.1.:Englewood Cliffs: Prentice Hall.

[7] Soejoeti, Z., 1987. Analisis Runtun Waktu, Materi Pokok UT.. Jakarta: Karunika.

[8] Cryer, J., 1986. Time Series Analysis. Boston: Publishing Company.

[9] Sun, J., \& Li, H. (2011). Dynamic financial distress prediction using instance selection for the disposal. Expert System with Application 38, 2566-2576.

[10] Widmer, G., \& Kubat, M. (1996). Learning in the Presence of Concept Drift and Hidden Contexts. Machine Learning, 69-101.

[11] Ghozali, I. (2009). Aplikasi Analisis Multivariate dengan Program SPSS. Semarang: UNDIP. 